\title{
History of Gulf Coast Citrus
}

\author{
James D. Spiers ${ }^{1}$ \\ Department of Horticulture, Auburn University, Auburn, AL 36849 \\ Claudine A. Jenda and Bridget S. Farrell \\ Auburn University Libraries, Auburn University, Auburn, AL 36849
}

\author{
Additional index words. Citrus unshiu, satsuma, Alabama, Florida, Louisiana, Mississippi, Gulf of Mexico, freeze injury
}

\begin{abstract}
Alabama, Louisiana, and Mississippi are not often thought of as citrus-producing states. However, citrus has been grown in the coastal regions of these states since the late 19th century. With a climate cool enough for a suitable amount of acid to remain in the fruit for optimum flavor and for adequate peel color development, the northern coastal fringe of the Gulf of Mexico from Louisiana to northwestern Florida is particularly well suited for production of the satsuma mandarin (Citrus unshiu Marc.), one of the most cold-hardy commercial citrus species. There were once thousands of hectares of satsumas planted in this region. Although satsumas typically reach optimum eating quality before fall freezes along the Gulf Coast, periodic severe freezes, as well as the occasional hurricane, prevented a citrus industry of this magnitude from remaining viable. Though freeze injury remains the primary limiting factor for citrus production in this region, there is great local interest, and a small industry focused on local markets has endured. Satsuma remains the primary citrus grown along the Gulf Coast region, though sweet oranges account for a large portion of citrus sales in Louisiana. This paper reviews the history of satsumas on the Gulf Coast, covering past and present production, cultivation, freeze protection strategies, pest issues, and marketing.
\end{abstract}

Though not widely known as a citrusproducing region currently, citrus production played a prominent role in the economic development of the Gulf Coast in the early 20th century. The region along the northern fringe of the Gulf of Mexico from the Texas Gulf Coast to the Suwanee River in Florida once contained vast plantings of satsuma mandarins (Citrus unshiu Marc.) (Rucker, 1996). Additional citrus, such as the 'Duncan' grapefruit (Citrus paradisi Macfadyen), 'Meyer' lemon (Citrus meyeri Yu. Tanaka), kumquats (Fortunella crassifolia Swingle and $F$. margarita Swingle), and sweet oranges (Citrus sinensis L. Osbeck), were and presently are grown on a much smaller scale in home orchards. However, it was satsumas that thrived in this region because of the well-suited climate and edaphic conditions. They thrived in the "Satsuma Belt" along the Gulf Coast in part because of the climate that is cool enough for adequate peel color development, but with a long enough growing season for satsumas to reach optimum eating quality before fall freezes. Satsumas quickly gained popularity in this region because of the palatability and the ease with which they can be consumed, and the marketing potential inherent in these attributes. The satsuma was called the "kid-glove orange" because it was said that a woman wearing kid gloves could peel and eat one without getting her gloves wet (Rucker, 1996). The growth of

Received for publication 25 May 2016. Accepted for publication 7 Oct. 2016.

This paper was presented as part of a Workshop titled "Fresh Perspectives on Citrus History" during the ASHS Annual Conference, which was held 4-7 August 2015, in New Orleans, LA.

We thank David Karp for the encouragement and assistance in editing earlier drafts of this article. We also thank Jamie Creamer for review of this article and Auburn University Libraries for allowing use of the pictures in this article.

${ }^{1}$ Corresponding author. E-mail: jds0017@auburn. edu. this industry was rapid; as about one million budded satsuma trees were imported from Japan from 1908 to 1911 (Tanaka, 1932). Many obstacles were overcome, such as the eradication of citrus canker and the standardization of varieties. Though periodic severe freezes ultimately prevented a citrus industry consisting of thousands of hectares from enduring in this region, the satsuma did much to populate and popularize the Gulf Coast. Evidence of this era along the Gulf Coast is indicated by the names of several towns and small communities including Orange, TX; Orange Grove, MS; Citronelle, AL; Orange Beach, AL; and Satsuma, AL.

The satsuma mandarin was introduced into Florida by George R. Hall in 1876 and again by Mrs. Van Valkenberg in 1878 (Hume, 1957; Tanaka, 1932). Known as "oonshiu" in Japan, the "satsuma" name is credited to Mrs. Van Valkenberg, the wife of a U.S. minister to Japan. Satsuma is the name of a former province, now Kagoshima Prefecture, where it was believed to have originated. Satsuma was budded on sour (Citrus aurantium L.) or sweet orange stocks initially, but its merit as a cold-tolerant commercial citrus fruit really became recognized after it was propagated on trifoliate orange (Poncirus trifoliata L.) stock, which came into actual cultivation in about 1885 (Bushway, 1909; Tanaka, 1932). During the great satsuma boom in the Gulf States from 1908 to 1911, about a million budded trees were imported to the United States from Japan for planting. The initial importation (190809 season) consisted mostly of the cultivar Ikeda. Subsequent importations from Japan consisted of half 'Ikeda' and half 'Owari' in 1909-10, about two-thirds 'Owari' and onethird 'Ikeda' in 1910-11, and finally almost exclusively 'Owari' in 1912-13 (Tanaka, 1932). 'Owari' was quickly favored for its superior fruit quality and is still highly regarded and the most widely planted cultivar along the Gulf Coast. By 1916, there were an estimated 8100 ha of satsumas in south Alabama alone (Shamel, 1921).

\section{Histories of Citrus Production by Individual Regions}

Texas Gulf Coast citrus production. Satsumas, and sweet oranges to a lesser extent, were extensively planted along the northern Gulf Coast section of Texas in the early 1900s, particularly in the vicinity of Houston and Beaumont (Vosbury, 1920). Based on the address of R.H. Bushway (Bushway, 1909), a prominent citrus grower in Texas, satsuma production was well underway in 1909, and growers had high expectations of rapidly increasing production. The advantages for production on the Texas Gulf Coast, as noted by Bushway (1909), included the vast land area suitable for production, rich soils, ample rainfall, an ideal climate, the very best transportation facilities to all the markets of the world, and an orange (satsuma) that matures and is ready to eat $90 \mathrm{~d}$ ahead of any other that is known. Unfortunately, many of these plantings were repeatedly killed back by cold, and in the winter of 1916-17, thousands of acres of citrus groves were frozen to the ground and abandoned (Vosbury and Robinson, 1929). The estimated citrus acreage in Texas in 1918 was 7113 (2879 ha), of which 1400 (567 ha) were satsuma (Vosbury, 1920). Henceforth, commercial plantings of citrus, mainly grapefruit, in Texas were restricted almost entirely to the lower Rio Grande Valley. Current citrus production statistics for the Texas Gulf Coast are not known.

Alabama Gulf Coast citrus production. The citrus industry in Alabama began with the introduction of satsuma, along with 'Duncan' grapefruit and kumquats ('Nagami' and 'Marumi') in Baldwin, Mobile, and Walker counties around 1900 (Marcus and Amling, 1976). In Alabama, the first planting of satsumas occurred in Baldwin County in 1898, though it was not until 1909 that satsuma production began to assume commercial importance (Winberg, 
1948). Oscar Fridolf Eskil Winberg, known as Dr. O.F.E. Winberg, was instrumental in the development of the satsuma industry along the satsuma belt. He moved from Chicago to Silverhill, AL, in 1905 and introduced scientific agriculture and the benefits of cooperative marketing to prospective farmers (Winberg, 1928). In 1910, Winberg started satsuma mandarin development on a commercial scale and devoted his energies toward the development of satsuma production throughout the Gulf Coast region. Dr. Winberg eventually became the president of the Gulf Coast Horticultural Society, president and manager of the Gulf Coast Citrus Exchange, and Chief Deputy Horticulturist of the Alabama State Board of Horticulture (Shamel, 1921). During this time, climatic and soil survey experts located a suitable belt, $\approx 100$ miles long, for satsuma production along the coast of Mississippi and Alabama (New York Times, 1915). The climate and edaphic condition in Baldwin and Mobile counties (the coastal counties of Alabama) were deemed very favorable for satsuma production (Wolf, 1912), and most of the groves were located there. The winter of 1911 had entailed severe losses to the orchardists and nurserymen of southern Texas, and some of them moved their nursery sites to these counties (Wolf, 1912). The success of early plantings sparked great enthusiasm and attracted investors (Williams, 1911; Wolf, 1912). Optimism for this developing industry was great. Williams (1911) stated "no fruit or vegetable yields or even promises to yield higher net returns per acre than satsuma oranges." An article in The New York Times stated that during the period 1911-15, in Mobile County alone, more than 10 million satsuma orange trees were planted and expected to produce 5000 carloads in 1916 (New York Times, 1915). Although the previously mentioned New York Times article is indicative of the enthusiasm for this industry, the actual amount of satsuma trees planted appears to be greatly embellished. There were reportedly 1357 citrus groves in Mobile County and 1100 in Baldwin County during the 1914-15 season, consisting of $1,758,590$ satsuma trees (Owen, 1921), and an estimated 8100 ha in these two counties by 1916 (Shamel, 1921). The industry received a severe setback with the hurricane of 1916 and the damaging cold temperatures of 1917 (Shamel, 1921; Vosbury and Robinson, 1929). Based on a survey by Dr. O.F.E. Winberg, there were reportedly
942,765 satsuma trees in Alabama in 1918 (Vosbury, 1920). The estimated number of citrus trees was 531,192 in 1919 (Vosbury and Robinson, 1929). Many of the trees that were lost due to injury in 1917 were replaced, and by 1923 , there were $\approx 8100$ ha of satsumas along the Gulf Coast of Alabama and Mississippi, with the bulk of the plantings in the two coastal counties of Alabama (Ferris and Richardson, 1923) (Fig. 1).

A report compiled by the U.S. Department of Agriculture for citrus production, use, and value provides a good perspective on the industry along the Gulf Coast from 1919 to 1965 (U.S. Department of Agriculture, 1967). According to the reported statistics, Alabama sales peaked in 1923 , with $225,000(40.8 \mathrm{~kg})$ boxes (Fig. 2). This coincides with Winberg's (1948) report of 700 carloads produced by Baldwin and Mobile counties in 1923. The acreage of bearing citrus, combined for Alabama and Mississippi, also peaked in 1923 (Fig. 3). The following year (1924), sales were negligible because of the coldest recorded temperature along the Gulf Coast since 1899 , $-11.7^{\circ} \mathrm{C}$ on $6 \mathrm{Jan} .1924$. Heavy freezes severely injured or killed hundreds of hectares of groves in 1924 (Vosbury and Robinson, 1929;

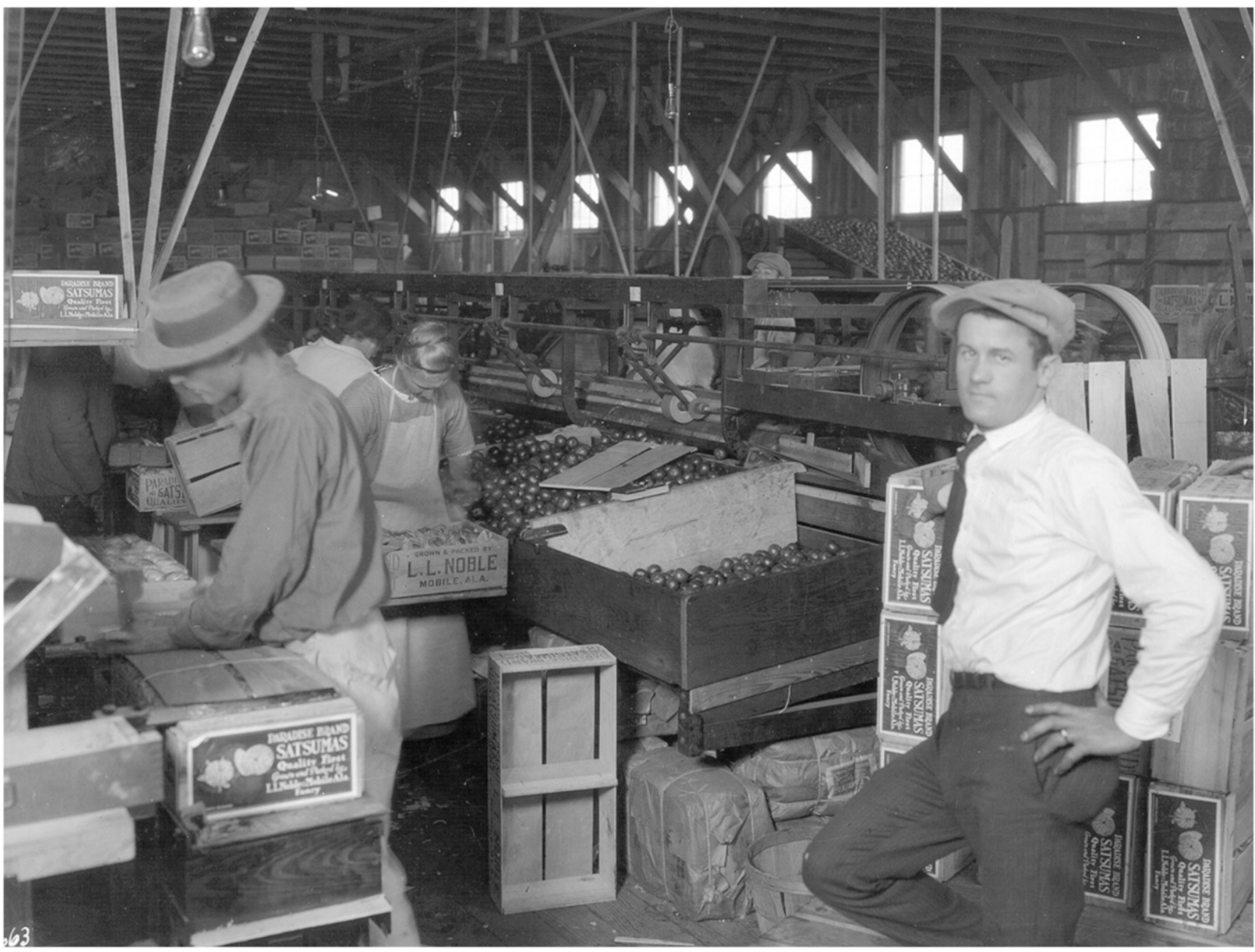

Fig. 1. Photograph of a satsuma packing plant in Mobile County, AL; 3 Nov. 1925. Photograph is courtesy of Auburn University Libraries. 


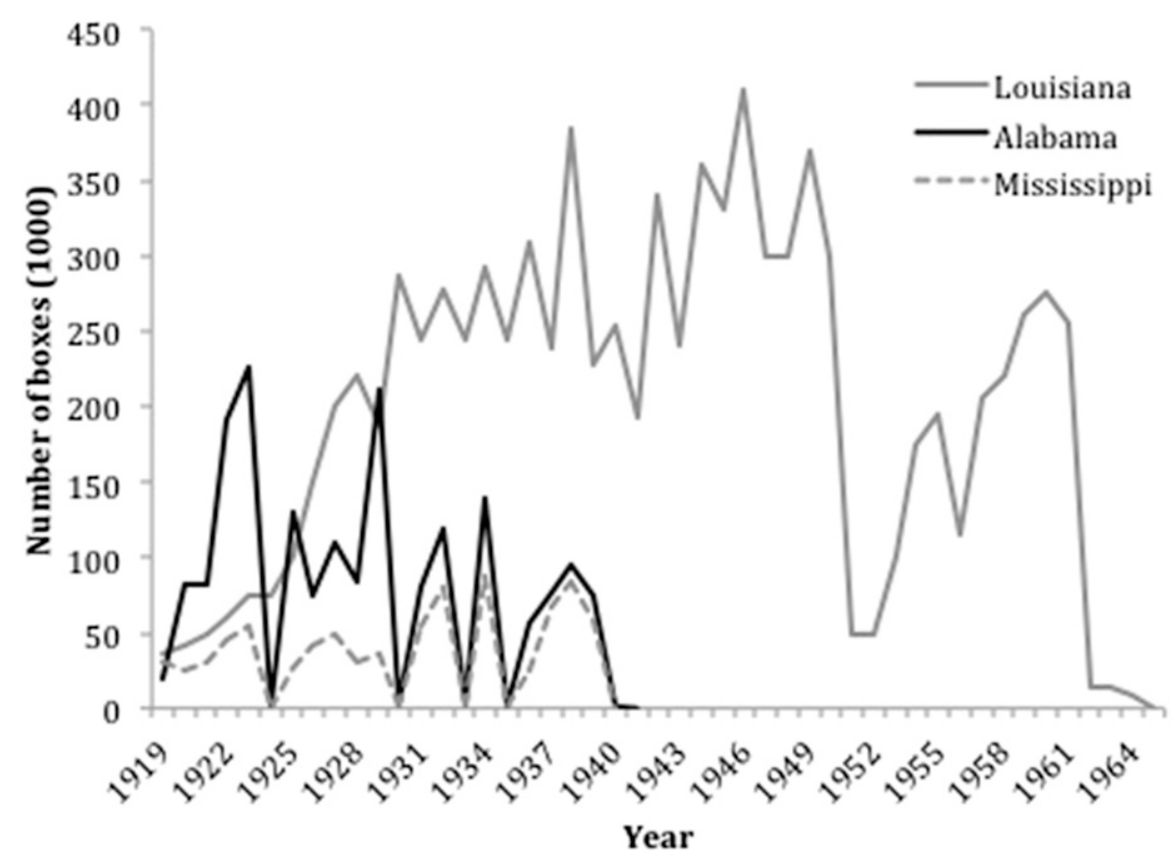

Fig. 2. The estimated number of $90-1 b$ boxes of citrus produced in Alabama, Louisiana, and Mississippi in the crop seasons of 1919-20 to 1964-65. Data were obtained from the U.S. Department of Agriculture (1967). Citrus fruits by states, 1909-10 to 1964-65, production, use, value, statistical bulletin no. 380. U.S. Dept. Agri., Washington, D.C.

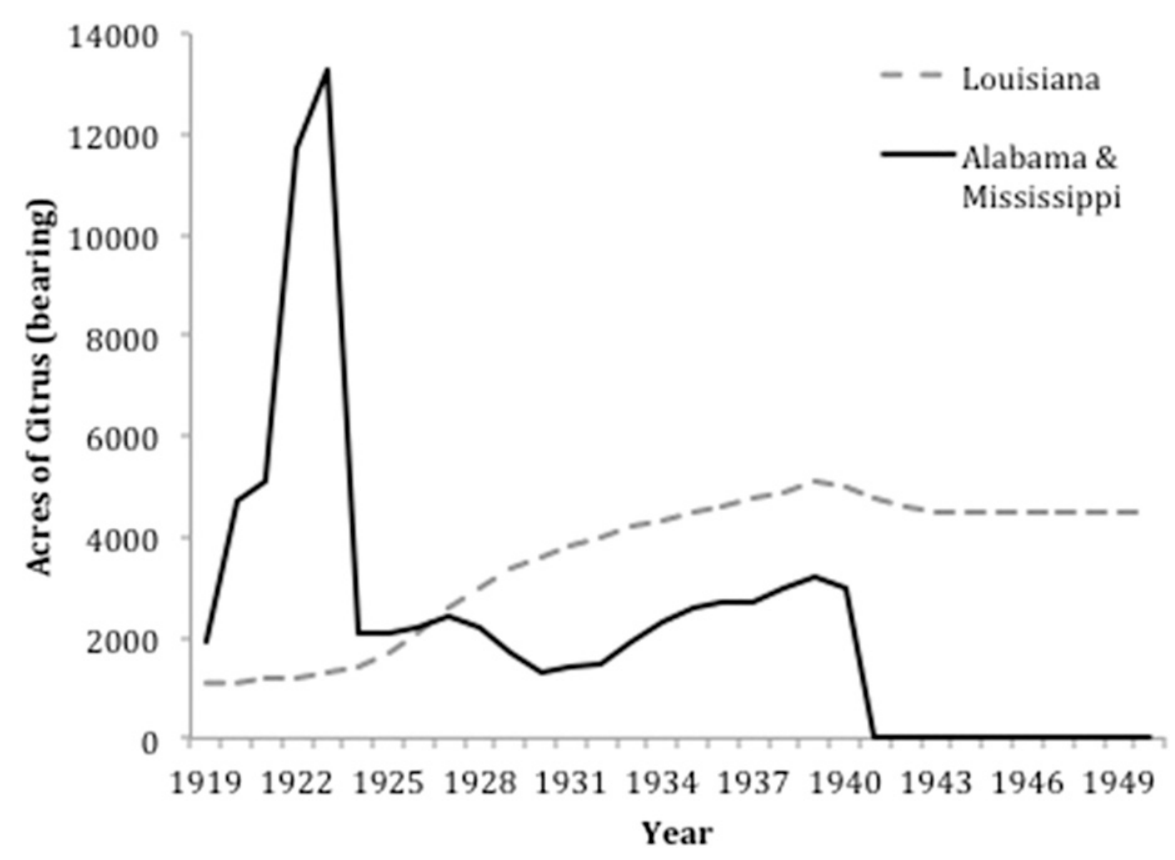

Fig. 3. The bearing acres of citrus for the crop seasons of 1919-20 and 1949-50 in Alabama and Mississippi combined, and Louisiana. Data were obtained from the following sources: U.S. Department of Agriculture (1945). Citrus fruits, production, farm disposition, value, and utilization of sales, crop seasons 1909-10 and 1943-44, U.S. Dept. Agr., Washington, D.C., U.S. Department of Agriculture (1952). Citrus fruits, production, farm disposition, value and utilization of sales, crop seasons 1944-45 and 1949-1950. U.S. Dept. Agr., Washington, D.C.

Winberg, 1948). These setbacks to the growers placed the satsuma industry in Alabama and Mississippi on a more conservative basis than in earlier years.

However, trees had recovered by 1925 , and 500 carloads were produced that season (Winberg, 1948). A severe storm in early fall amounted to a gross of 10 million dollars (Winberg, 1948). Ten million dollars in the 1920 s equates to about $\$ 140$ million in 2016 (U.S. Bureau of Labor Statistics, 2016). Then, the tumultuous, Depression-era 1930s ensued. Severe freezes occurred in 1930, 1933, and twice in 1935. As a result, there was a gradual dying out of trees due to freeze injury. Then, on 20 Nov. 1940, there was a sudden change in temperature from 26.7 to $-6.7^{\circ} \mathrm{C}$. Trees were not quiescent because of unseasonably warm weather, and the injury was considerable (Winberg, 1948). The winter of 1940 marked the end of the Gulf Coast Citrus Exchange and the end of an era along the Gulf Coast. Though miniscule compared with the golden age of satsuma production in the early twentieth century, satsumas were undoubtedly planted in southern Alabama and Mississippi from 1940 through 2000, though no citrus production was reported in Census of Agriculture data until recently. The most recent report estimated 93.5 ha of citrus production in Alabama (U.S. Department of Agriculture, 2014).

Mississippi Gulf Coast citrus production. The satsuma industry in southern Mississippi, compared with the industry in Alabama, consisted of smaller commercial plantings in George, Hancock, Harrison, Jackson, Pearl River, and Stone counties (Ferris and Richardson, 1923). There were reportedly 66,992 citrus trees in Mississippi in 1919 (Vosbury and Robinson, 1929). In 1923, the largest combined acreage of bearing trees in Mississippi was located in Stone County near Wiggins, with a total of at least 61 ha (Ferris and Richardson, 1923). In subsequent years, most of the production was located in the coastal counties of Hancock, Harrison, and Jackson (Overcash, 1976). In 1925, there were an estimated 71,590 citrus trees in Mississippi (Vosbury and Robinson, 1929). The Mississippi Gulf Coast satsuma industry experienced the same injurious weather events observed on the Alabama Gulf Coast and had negligible production for the seasons of 1924-25, 1930 $31,1933-34$, and 1935-36 because of freeze injury (Fig. 2). In terms of boxes sold, the Mississippi satsuma industry peaked in 1934 35 , with 88,000 boxes sold (Fig. 2). The highest grossing year was 1927-28, with production valued at $\$ 166,000$ (U.S. Department of Agriculture, 1967) or \$2.3 million in 2016 dollars (U.S. Bureau of Labor Statistics, 2016). Similar to Alabama, the cold winter of 1940 effectively ended large-scale commercial satsuma production in Mississippi (Winberg, 1948). Satsumas are presently grown on the Gulf Coast of Mississippi in home orchards or small-scale commercial production (Nesbitt et al., 2008; J.D. Spiers, unpublished data).

West Florida Gulf Coast citrus production. There was great enthusiasm for satsuma production in west Florida by the early 1920 s. Before the 1920s, there were few plantings in west Florida, but by 1924 , satsuma production was estimated at 3237 ha, with plantings limited only by the number of available nursery trees (DeBusk, 1924). 
Satsuma production was attempted in central and southern Florida, but the resultant fruit were of unsatisfactory quality (Vosbury and Robinson, 1929). E.F. DeBusk, one of the Florida citrus's greatest publicists, hoped that "with the arrival of the golden, delicious, satsuma upon citrus markets of the country, the suicidal practice of shipping green fruit from central and south Florida will automatically stop forever" (DeBusk, 1924). Companies produced numerous publicity pamphlets and promotional magazines to lure investors, and such efforts intensified with the Florida land boom of the 1920s (Rucker, 1996). Timber resources, which had earlier played such an important role in the region's economy, were depleted by this time, and satsumas offered the best opportunity to transform these lands into productive groves (Rucker, 1996). "Satsumaland" was the name often given to the western portion of Florida stretching from the Perdido River to Apalachicola (Rucker, 1996). There were reportedly 528,823 satsuma trees in Florida, presumably west Florida, in 1928 (Vosbury and Robinson, 1929). There were 724,768 satsuma trees in Florida in 1931 (University of Florida, 1934). In the early to mid-1930s, 45 cities in the United States were markets for Satsumaland and the Gulf Coast Citrus Exchange (Rucker, 1996). Jackson County, where the headquarters of the Satsumaland Fruit Growers Association was located, became one of the most important centers for satsuma cultivation (Rucker, 1996). The Marianna Satsuma Orange Festival in Jackson County reportedly had 15,000 visitors in 1928 and more than twice that in 1929 (Rucker, 1996).

Almost as rapidly as it had commenced, the citrus industry of west Florida began to deteriorate. The collapse of the Florida land boom in the mid-1920s caused real estate developers, who had greatly emphasized the potential of citrus fruit, to decrease their marketing efforts (Rucker, 1996). The infamous stock market crash of 1929 occurred, and the region began to feel the effects of the nation's deepening depression (Rucker, 1996). However, it was cold weather that marked the end of Satsumaland. Similar to the industries in Alabama and Mississippi, several injurious freeze events occurred in the 1930s. A severe freeze in 1935 resulted in the loss of most of the groves, and the brutally cold month of Jan. 1940 ended the satsuma industry in west Florida (Rucker, 1996; Winberg, 1948). Currently, there are a few small-scale satsuma groves in west Florida, most notably in Jackson County, with about 6 ha in production (M. Lollar, personal communication).

Louisiana Gulf Coast citrus production. In Louisiana, citrus fruits have been grown longer than in any other region along the Gulf Coast on a narrow area on either side of the Mississippi River south of New Orleans. The first orange trees planted in Louisiana were planted by Father La Rue, a Jesuit missionary, at Fort Mississippi, about 35 miles south of New Orleans in about 1700 (Hawthorne, 1976). In about 1800 , several small citrus groves consisting of trees grown from seeds were planted in Plaquemines Parish. In 1904, citrus fruit from this area, produced from budded trees, were exhibited at the World's Fair in St. Louis, MO. The first known successful introduction of mandarins into the United States was made by the Italian consul at New Orleans between 1840 and 1850 and consisted of the Mediterranean mandarin that came to be known as Willowleaf mandarin in this country (Hodgson, 1967).

Sweet oranges and satsumas were successfully grown in the protected area along the river levee in Plaquemines Parish, and extensive plantings were made on land previously devoted to sugarcane just before 1920 (Vosbury and Robinson, 1929). During the satsuma boom, extensive plantings of satsuma occurred in other sections of Louisiana, but losses from killing frosts resulted in many being abandoned (Vosbury, 1920). Vosbury (1920) stated that the estimated citrus production in Louisiana was 8094 ha in 1915 and was reduced by half or more after the cold winter experienced in 1917. With exception to the region south of New Orleans, it was recommended to restrict plantings to small groves in the most frost-free sites. However, citrus-bearing acreage steadily increased in Louisiana from 1920 to 1940 (Fig. 3). Historically and presently, most of the citrus production is south of New Orleans in Plaquemines Parish, a distinctly warmer region compared with the rest of the Gulf Coast. As shown in Fig. 2, the Louisiana citrus industry did not experience any years with negligible production until the 1960s, whereas Alabama and Mississippi had several years of negligible production due to freeze injury from 1920 to 1940 (Fig. 2). Citrus production peaked in 1946, in terms of boxes sold, at 410,000 (Fig. 2). In fact, citrus production and the value of the crop were consistently substantial throughout the 1940s (U.S. Department of Agriculture, 1967). Citrus crop value averaged $\$ 651,000$ for the 1940 s, with a peak value of $\$ 936,000$ in 1944 that equates to about $\$ 12.8$ million in 2016 dollars (U.S. Bureau of Labor Statistics, 2016). Owing to the warmer climate, this industry prevailed. There was a severe freeze from 1 to 3 Feb. 1951, but afterward, the industry was on the rise again. The value of the crop was $\$ 1,031,000$ (275,000 boxes) in 1960 (U.S. Department of Agriculture, 1967), or about $\$ 8.4$ million in 2016 dollars (U.S. Bureau of Labor Statistics, 2016). The 1960 s, however, was a rough time for citrus producers in Louisiana. Severe cold in January 1962, two freeze events in 1963, Hurricane Betsy in 1965, and Hurricane Camille in 1969 devastated the industry. Fifteen thousand boxes were produced in 1962 and 1963 , followed by 8000 in 1964, and then no production was reported for the rest of the 1960s (U.S. Department of Agriculture, 1967). By 1975 , there were $\approx 1093$ ha of citrus in Louisiana, of which 890 ha were located in
Plaquemines Parish (Law et al., 1975). Bearing acreage declined steadily from 1978 ( $\approx 546 \mathrm{ha})$ to 0 in 1992 because of several severe freezes, most notably in 1989 when Lake Pontchartrain was partially frozen over $(\approx 100 \%$ tree death $)$. There are very few, if any, commercial citrus trees along the Gulf Coast that were planted before 1989. Hurricane Katrina caused significant injury to the Louisiana citrus industry, with about half of the citrus trees lost in Plaquemines Parish. However, the northern half of Plaquemines had a bumper crop in 2007 (American Press, 2007). According to the 2012 census of agriculture, there were 387 ha of citrus production in Louisiana (U.S. Department of Agriculture, 2014). Currently, 'Washington' navel oranges [Citrus sinensis (L.) Osbeck] and satsumas account for the majority of the citrus produced in Louisiana, followed by 'Louisiana Sweet' or 'Plaquemines' sweet oranges (C. Johnson, personal communication).

\section{Causes of the Rise and Early Success of the Gulf Coast Citrus Industry}

Several factors contributed to the rapid rise in production of satsumas along the Gulf Coast, particularly in Alabama, Mississippi, and Florida. A key component was that vast areas of longleaf pines (Pinus palustris Mill.) had been logged by the early 1900s, leaving the land practically barren. Converting the substantial acreage to satsuma production added value back to the land, such that logged pineland that was worth $\$ 12.50 /$ ha in $\approx 1910$ had jumped to $\$ 125 /$ ha by 1915 (New York Times, 1915). Another contributing factor was that the boll weevil was advancing in Alabama, which forced attention to cultivation of crops other than cotton (Williams, 1911). Access to a central shipping point, namely Mobile, which had direct railroad lines to the north and east, facilitated the rapid growth of the satsuma industries in Alabama, Mississippi, and Florida (Rucker, 1996; Williams, 1911). Perhaps of utmost importance, there were no severe freeze events from 1900 to 1915 .

Another major component of this once thriving industry had to do with cooperation among growers and cooperation among researchers, extension agents, and growers. A cooperative association of the growers, known as the Gulf Coast Citrus Exchange, provided crucial assistance in the development of the marketing end of the industry (Winberg, 1948). The Gulf Coast Citrus Exchange originated in Mobile in 1915 (Winberg, 1948). This cooperative became the leading satsuma promoter and was responsible for grading, handling, and marketing $\approx 75 \%$ of the satsuma crop (Rucker, 1996). Satsumas were marketed to cities throughout the northern United States, particularly Chicago and New York City. The Gulf Coast Citrus Exchange supervised the construction and equipment of cooperative packing houses (Fig. 1), and the cooperative marketing of fruit from the entire satsuma 
belt (Ferris and Richardson, 1923), including Louisiana, Mississippi, Alabama, and west Florida. In the fall of 1922, one of the first railcars of satsumas from the packing house at Lyman, MS (Orange Grove community), went to Montreal, Canada, and arrived in good condition (Ferris and Richardson, 1923). Refrigerated steamers from Mobile, Gulfport, and Pensacola eventually took satsumas to Europe, particularly London (Rucker, 1996). The Gulf Coast Citrus Exchange marketed its satsumas as follows: first grade, Sugar Sweet; second grade, Gulf Breeze; and third grade, Sunny South (Shamel, 1921). Similar to the role of the Florida State Horticultural Society within the main citrus sections of Florida, the Gulf Coast Horticultural Society was a valuable agency for promoting social and business relations of the citrus growers along the Gulf Coast of Alabama, Florida, and Mississippi (Vosbury and Robinson, 1929). As a testament to the guidance provided by the Gulf Coast Horticultural Society, W.T. Swingle, a prominent citrus authority, said that the Alabama satsuma development was the most scientifically founded of any citrus industry in his experience (Shamel, 1921). As previously noted, O.F.E. Winberg was the president of the Gulf Coast Horticultural Society and the Gulf Coast Citrus Exchange, and his leadership contributed greatly to the early success of this industry.

\section{Production Practices}

Though initially satsumas were thought to be all of one type, an individual tree investigation of groves by T. Tanaka, author of "Varieties of the Satsuma Group in Japan," and others revealed that there were at least three varieties in Alabama: 'Owari', 'Ikeda', and 'Zairai' (Ferris and Richardson, 1923; Shamel, 1921). 'Owari' was considered the most valuable commercially, and a concerted effort was made to propagate this variety principally from budwood secured from parent trees that recorded superior performance based on fruit quality, production, and other desirable characteristics of the trees (Shamel, 1921). Efforts to standardize and improve citrus nursery stock propagated and sold in Alabama were revolutionary for the time and viewed with great interest by citrus leaders in other states (Shamel, 1921). The Alabama State Board of Horticulture adopted "Rules and Regulations Governing the Propagation and Sale of Citrus Nursery Stock in Alabama" in 1920. Detailed records were kept on the condition of satsuma trees in groves within the citrus belt of Alabama, and any individual or entity could apply to the State
Board of Horticulture for information as to where to obtain suitable propagative material. Every lot of citrus plants produced in Alabama was required to be accompanied with a certificate bearing the name of the nursery, the variety, the number of the block in the nursery where the trees were secured, and the name of the grove where the budwood was obtained (Shamel, 1921).

It was recommended to only use trifoliate orange as the rootstock (Bushway, 1909; Swingle, 1909; Williams, 1911; Wolf, 1912) as it is the most freeze-tolerant rootstock commonly used for citrus. Trifoliate orange is deciduous, having a distinct dormant season in winter, and when used as a rootstock, is associated with reduced freeze injury (Swingle, 1909). Even though satsumas grafted onto trifoliate orange rootstock are perhaps the most freeze-tolerant commercial citrus (Yelenosky, 1985), freeze injury was always a concern, and citrus growers were advised to not rely on satsuma production alone in the early days of this developing industry (Williams, 1911). Many of the large groves were initially planted with satsumas interspaced with pecans, particularly in Alabama (Fig. 4). Williams (1911) stated that the pecan trees would eventually overshadow the satsumas, but a considerable income would be realized on the latter before it became

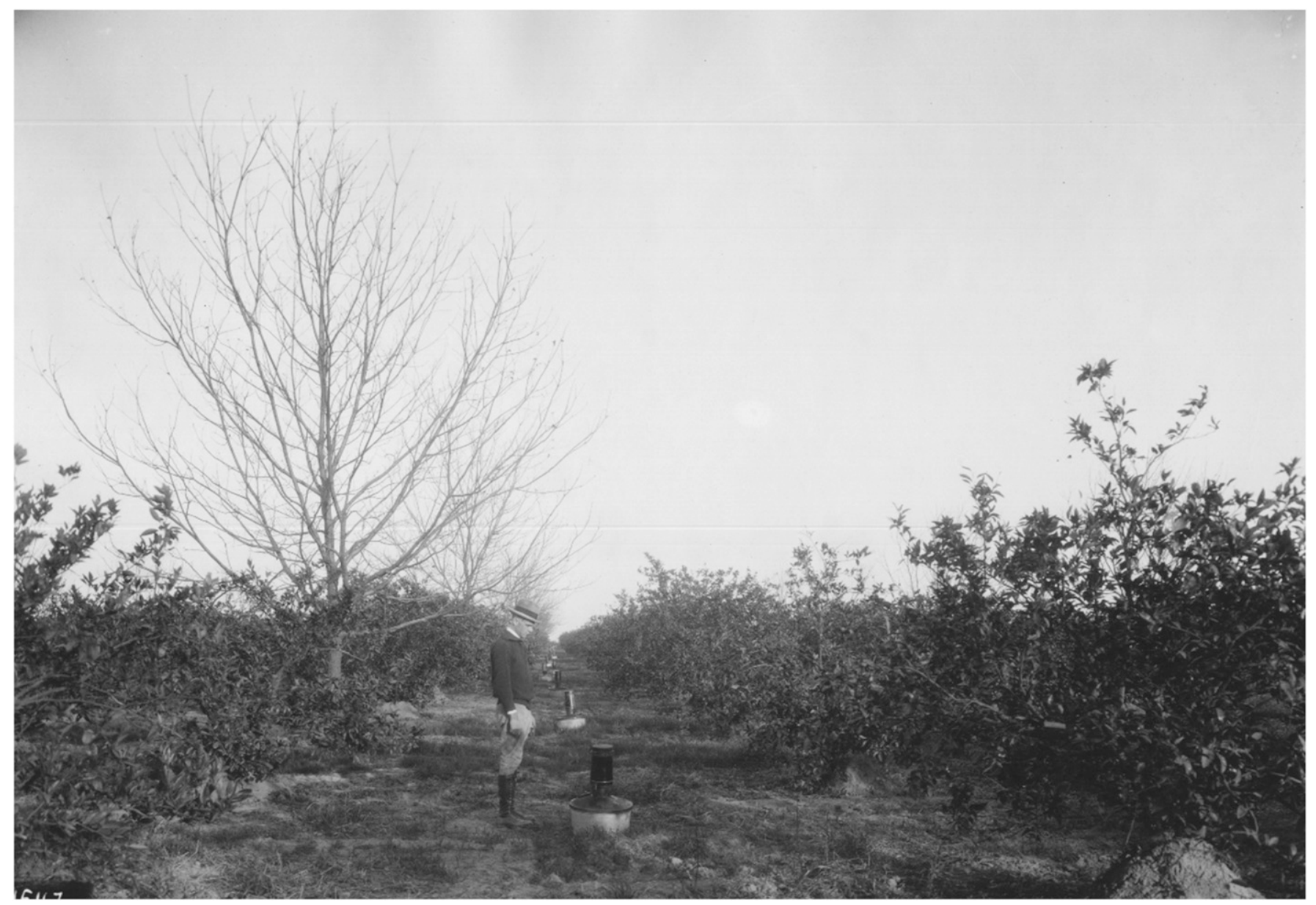

Fig. 4. Photograph of a satsuma grove interplanted with pecan trees in Mobile County, AL; 4 Feb. 1927. Satsuma trees were banked, and smudge pots were placed between rows for freeze protection. Photograph is courtesy of Auburn University Libraries. 
necessary to remove them. For most of these groves, the plan was to remove satsumas when pecans came into bearing, but because of the early success of the satsumas, many of the orchardists removed the pecan trees instead (Shamel, 1921).

Freeze protection. Freeze injury has historically been the most limiting factor for satsuma production along the Gulf Coast. Many methods of frost protection have been advocated for citrus groves. As with all crops susceptible to freeze injury, avoiding frost pockets via site selection is a primary tool. Advective freezes pose the most significant danger to satsumas. Banking or mounding, particularly young trees, was the predominant recommendation for cold protection (Bushway, 1909; Clayton, 1922; University of Florida, 1934; Williams, 1911; Winberg and Starcher, 1918). Banking is a proven practice that resulted in saving many trees. Evidence of the effectiveness of banking was described in several publications after the freeze of 1917 (Vosbury, 1920; Vosbury and Robinson, 1929; Winberg and Starcher, 1918) and the freeze of 1924 (Vosbury and Robinson, 1929). Banking reportedly saved 4-year-old trees from certain death when a sudden drop in temperature to $-11.1{ }^{\circ} \mathrm{C}$ occurred on 6 Jan. 1924 (Anderson, 1928). The trees died back to the bank, but once cut back, they grew several feet by the end of the growing season. Wood fires and coke or oil heaters were advocated and used effectively in some cases. Figure 4 illustrates cold protection techniques used at a grove in Mobile County, AL, in 1925. Satsuma trees were banked to above the graft union with smudge pots placed in between rows (Fig. 4). Several groves were protected by wood fires in 1917, when a low of $-6.1{ }^{\circ} \mathrm{C}$ severely injured unprotected groves (Vosbury, 1920). Usually, one pile of wood was placed between every square of four trees, and in many cases, it was not necessary to light more than each alternate pile until the cold became intense.

Recommendations concerning windbreaks varied. Winberg and Starcher (1918) advocated no windbreaks after observing injury due to the freeze of 1917. Possibly because of their report, several subsequent publications recommended that no windbreaks should be used, as anything that interferes with the free circulation of air through the grove should be avoided (Clayton, 1922; Ferris and Richardson, 1923; University of Florida, n.d.). It was recommended to open up windbreaks or bodies of timber adjoining a satsuma grove on the north and west to allow air drainage because the cold air would likely pass over the timber and settle in any depression or pocket (Clayton, 1922). Later publications advocated windbreaks on the windward side of a grove (University of Florida, 1934; Vosbury and Robinson, 1929). The disparity in recommendations for windbreaks could be due to the variability in prevailing winds along the Gulf Coast.

Eventually, some strains of satsuma were selected for apparent enhanced cold hardiness. 'Silverhill' was a nucellar seedling selection of 'Owari' that faired better than
'Owari' in several severe freeze events (Swingle and Robinson, 1931). Much later, 'Kimbrough' was selected from a seedling of 'Owari', in part because of perceived enhanced cold tolerance (Brown et al., 1976).

Planting, irrigation, and fertilization. Many of the early plantings were spaced $4.57 \mathrm{~m}$ apart $(15 \times 15 \mathrm{ft})($ Shamel, 1921), but with experience, the recommendations for spacing were generally increased to 6-7.6 m (20-25 ft) apart (Ferris and Richardson, 1923; University of Florida, 1934; Vosbury and Robinson, 1929). O.F.E. Winberg recommended a spacing of $7.3 \times 4.9 \mathrm{~m}(24 \times 16 \mathrm{ft})($ Shamel, 1921). Very few groves were initially irrigated, but those that were used furrow irrigation. A furrow-manure system of applying manure or other organic fertilizer, in which the organic fertilizer was placed in deep furrows located in or near the active feeding root zone of the trees, was successfully used in many groves (Shamel, 1921). Shamel (1921) noted that in every community he visited in south Alabama, one or more dairies were found, which made possible the use of good cow manure in the citrus groves at reasonable prices. Small applications of inorganic fertilizer were also applied annually in many groves. The Gulf Coast Citrus Exchange principally handled this fertilizer so that growers could secure it at a minimum cost. Fertilization recommendations and practices varied considerably. It was recommended to fertilize only twice a year, spring and early summer, and apply no fertilizer after June or July to avoid late vegetative growth that would compromise cold resistance (Vosbury and Robinson, 1929).

Cover crops. Year-round clean cultivation was once widely practiced in citrus groves in Florida, but it was eventually found that this method rapidly depleted the soil (Vosbury and Robinson, 1929). Based on this knowledge, most groves in the satsuma belt used cover crops for at least part of the year. The soil in the groves was usually plowed in early spring. In many cases, summer cover crops of cowpea [Vigna unguiculata (L.) Walp.] were grown, but many growers preferred clean cultivation during the summer (Vosbury and Robinson, 1929). Winberg and Starcher (1918) recommended clean cultivation from spring until as late as Oct. 1. In the winter, a volunteer cover crop was allowed to grow, which was plowed under the following spring. Shamel (1921) observed that some groves in south Alabama had sowed winter cover crops of sweet clover [Melilotus indicus (L.) All.].

Pruning. Very little pruning was done, for the most part. It was observed that frequent and rather severe pruning resulted in light crops of fruit (Shamel, 1921). Hence, it was recommended to remove dead or injured growth or undesirable branches but to otherwise avoid pruning. When a severe freeze event occurred, it was recommended to prune as soon as freezing injury could be determined (Winberg and Starcher, 1918).

Degreening satsumas. Satsumas typically develop good flavor, juice, sugar/acid ratio, and fully colored pulp while the peel is completely or partially green (Hume, 1957).
Satsumas grown along the Gulf Coast often reach a high degree of palatability (and the required 8:1 soluble solids to acid ratio) weeks before the peel attains the characteristic golden yellow color (Wright, 1923). If the fruits are held until fully colored, the acidity decreases, and the grower risks the fruit becoming insipid. Marketing satsumas early also reduces the risk of freeze injury and permits market entry before Florida oranges are mature (Wright, 1923). Hence, it was important to ship the fruit as early as possible so that its value as an early ripening variety was not lost. However, green fruit is difficult to merchandise. Because the current Gulf Coast satsuma acreage is small and destined for local markets, most producers delay harvest until cool conditions provide good peel color (Ebel et al., 2004; Reuther, 1973). During the early twentieth century, satsumas were grown on a large scale and were widely exported, so poor color resulted in extensive cullage. Satsuma growers in Alabama had success in coloring the fruits artificially by using fumes from kerosene stoves (Wright, 1923), and gas-tight rooms for coloring became associated with packing houses throughout the Gulf States (Louisville and Nashville Railroad, n.d.). For packing houses powered by gasoline engines, Wright (1923) provided a design for a "coloring plant" that used the exhaust fumes to color overly green satsumas. If a larger house was operated or if a gasoline engine was not used for power, it was recommended to use a kerosene stove. The temperature was recommended to be $\approx 24{ }^{\circ} \mathrm{C}$, and humidity was kept high via humidifiers, wet bags, and throwing buckets of water on the floor in the aisle to avoid fruit shrinkage. As there were no means of measuring the concentration of gas, the operator was forced to rely on experience to determine the amount present. Wright (1923) described that in a well-regulated room, "one should experience only a slightly disagreeable odor and a burning sensation of the eyes. It is not necessary to stay in the room, as the first sensation experienced is the most reliable." He further noted that staying in the room for more than a minute or two would likely result in severe headache, nausea, or even death. Coloring was ordinarily complete in four days if the fruit was sufficiently matured and carried at least $5 \%$ of yellow color when placed in the room. This procedure enabled growers to get their fruit on the market 46 weeks sooner than if it were left to color on the trees (Wright, 1923). Degreening with controlled levels of ethylene is currently the commonly used procedure for citrus (Arpaia et al., 2014).

Pest management. Though there are many additional pests of citrus, the major insect pests for Gulf Coast satsumas included the purple scale (Lepidosaphes beckii Newm.), rust mite (Phyllocoptes oleivorus Ash.), citrus whitefly (Dialeurodes citri Ash.), and citrus red mite (Panonychus citri McG.) (English and Turnipseed, 1940). Purple scale was first reported in south Alabama in 1914 and became the most important insect pest in 
that region (English and Turnipseed, 1940). After the eradication of citrus canker (Xanthomonas citri subsp. citri), sour scab (Elsinoë fawcettii syn. Sphaceloma fawcettii Jenkins), also called citrus scab, was considered to be the most important citrus disease along the Gulf Coast. In groves relatively free of scale, scab was likely to be the major problem (English and Turnipseed, 1940). Five spray mixtures were recommended to combat pests: Bordeaux mixture (copper sulfate, lime, and water; $\approx 3-3-50$ ) for sour scab, oil emulsion for scale insects and white flies, Bordeaux-oil emulsion for scab and scales, lime sulfur for mites and scale, and nicotine sulphate for thrips (Louisville and Nashville Railroad, n.d.).

Citrus canker. Citrus canker was introduced into the Gulf States from Japan on nursery stock (Wolf, 1916). The disease was first brought to Wolf's attention in Feb. 1914. The Office of Nursery Inspection of Florida collected specimens in Sept. 1912 but did not realize the presence of a new citrus disease until July of the following year. By 1916, the disease had been verified in all of the Gulf States in regions adapted to the growth of citrus trees. A very small percentage of trees were affected with citrus canker at this time (1916), but it was realized that these few trees were a serious menace to the citrus industry in the Gulf States. It was therefore recommended that energetic efforts be made to prevent further introduction and spread, and to eradicate the disease already present. Wolf (1916) noted that the grapefruit and trifoliate orange seem to be much more susceptible than other species, whereas satsuma appeared to be quite resistant. Satsuma trees growing in rows adjacent to badly diseased grapefruits had been observed to remain free of disease during an entire season. Control efforts were directed along three lines: exclusion, protection, and eradication. Further introduction of diseased material was prevented by federal quarantine. The Gulf Coast states themselves passed regulatory measures to prevent the further spread of canker within the states and across state lines. Initial efforts were confined to removal of diseased parts of the tree, the rest being treated with Bordeaux mixture, but this was ineffective. The only viable method known to control citrus canker is the complete destruction of all infected trees. Hence, a concerted citrus canker eradication campaign was initiated throughout the Gulf States. The U.S. Bureau of Plant Industry, the Alabama State Board of Horticulture, and the growers successfully fought citrus canker until it was practically eradicated in Alabama by 1921 (Shamel, 1921). In Florida, it was declared eradicated in 1933 (Dopson, 1964).

Current citrus production. The satsuma occupied a unique position in the development of the Gulf Coast region. The vast satsuma groves with trees laden with golden fruit in the fall left a lasting impression on many visitors and increased commerce and development. The grand scale of the satsuma industry in the Gulf States $\approx 1911-40$ proved to be unsustainable because of periodic severe freezes. However, satsuma production will likely always be a part of this region. Satsumas are currently grown on a more limited basis and not typically as the sole source of livelihood. Freeze injury remains the most limiting factor for satsuma production. Satsuma growers in Alabama attempt to mitigate freeze injury by using various orchard designs such as interplanting between pecan or pine trees, planting in open fields with microsprinkler irrigation, and planting behind windbreaks (Harrison et al., 2013a, 2013b; Nesbitt et al., 2008). Microsprinkler irrigation is recommended and has been proven to provide enhanced cold protection (Ebel et al., 2008; Nesbitt et al., 2000), and larger plantings in Alabama (2-9 ha) usually include this technology. Dense pine tree canopies can provide an insulating effect that reduces freeze injury and yield losses when severe freezes occur, but heavy shading reduces yields when damaging freezes do not occur and, for this reason, is not recommended (Harrison et al., 2013a). In areas of increased freeze risk, "high tunnel greenhouse" production, with trees planted in greenhouses that are covered from December to April with a single layer of white, 4- or 6-mil polyethylene plastic, is used (Nesbitt et al., 2008). Poncirus trifoliata remains the recommended rootstock for satsumas grown along the Gulf Coast because of excellent cold hardiness (Yelenosky et al., 1973). The P. trifoliata cultivar Rubidoux is the most widely used citrus rootstock in the region, but several growers are using 'Flying Dragon' to produce smaller trees, particularly for high tunnel production (Nesbitt et al., 2008). 'Owari' remains the predominant cultivar of satsuma grown in the region and typically reaches desirable eating quality in early to mid-November (Ebel et al., 2004). Several satsuma cultivars that ripen $\approx 30 \mathrm{~d}$ earlier are grown to a lesser extent, including 'Armstrong Early', 'Okitsu Wase', 'Xie Shan', 'Early St. Ann', and 'L.A. Early'. 'Brown's Select' is often grown as a midseason cultivar and ripens 7-20 d earlier than 'Owari' (Nesbitt et al., 2008). 'Washington' navel oranges and several sweet orange cultivars are produced commercially in south Louisiana, but no navel or sweet orange cultivars are grown commercially in the other Gulf States (Nesbitt et al., 2008).

\section{Literature Cited}

American Press. 2007. LSU AgCenter: Louisiana citrus crop better than expected. American Press, Lake Charles, LA. 5 Dec. 2007. <http:// infoweb.newsbank.com/resources/doc/nb/news/ 11D5F2AF69981A10? $\mathrm{p}=\mathrm{AWNB}>$.

Anderson, W.S. 1928. Growing satsuma oranges in South Mississippi. Mississippi Agric. Expt. Stat. Bul. No. 265.

Arpaia, M.L., J.E. Adaskaveg, J. Smilanick, and R. Elliott. 2014. Postharvest handling, p. 370-371. In: L. Ferguson and E.E. Grafton-Cardwell (eds.). Citrus production manual. University of California Agriculture and Natural Resources, Oakland, CA. Publication 3539.

Brown, R.T., P.L. Hawthorne, J.E. Love, D.W. Newsom, and T.J. Raiford. 1976. Kimbrough: A new cold hardy satsuma variety. Louisiana Agric. Expt. Stat. Circular No. 102.

Bushway, R.H. 1909. The Satsuma orange for profit in Texas. Proc. Texas State Hort. Soc.

Clayton, H.G. 1922. Satsuma oranges in north and west Florida. Florida Coop. Ext. Bul. 33.

DeBusk, E.F. 1924. The satsuma industry of north and west Florida. Fla. St. Hort. Soc. 139-141.

Dopson, R.N. 1964. The eradication of citrus canker. Pl. Dis. Rept. 48:30-31.

Ebel, R.C., M. Nesbitt, W.A. Dozier, B. Hockema, F.M. Woods, R. Thomas, B.S. Wilkins, and R. McDaniel. 2004. Fruit quality of satsuma mandarin grown on the northern coast of the Gulf of Mexico. HortScience 39:979-982.

Ebel, R.C., M. Nesbitt, W.A. Dozier, Jr., and F. Dane. 2008. Freeze risk and protection measures of satsuma mandarins grown in the southeastern United States. HortScience 43:287-289.

English, L.L. and G.F. Turnipseed. 1940. Control of the major pests of satsuma orange in south Alabama. Alabama Agr. Expt. Sta. Bul. 248.

Ferris, E.B. and F.B. Richardson. 1923. The satsuma orange in South Mississippi. Mississippi Agr. Expt. Sta. Bul. No. 217.

Harrison, M.R., J.D. Spiers, E.D. Coneva, W. Dozier, and F.M. Woods. 2013a. Orchard design influences fruit quality, canopy temperature, and yield of satsuma mandarin (Citrus unshiu 'Owari'). Intl. J. Fruit Sci. 13:334-344.

Harrison, M.R., J.D. Spiers, E.D. Coneva, F.M. Woods, J.R. Kessler, Jr., and W.A Dozier Jr. 2013b. Influence of orchard design on 'Owari' satsuma mandarin Citrus unshiu (Marcovitch) fruit quality, physiology, and productivity. J. Amer. Pom. Soc. 67:34-46.

Hawthorne, P.L. 1976. Louisiana, p. 64-65. In: D.V. Fisher and W.H. Upshall (eds.). History of fruit growing and handling in United States of America and Canada, 1860 - 1972. American Pomological Society, Regatta City Press, Kelowna, BC, Canada.

Hodgson, R.W. 1967. Horticultural varieties of citrus. In: Citrus industry, vol. 1. <http:// websites.lib.ucr.edu/agnic/webber/Vol1/Chapter4. $\mathrm{html}$ \#mandarins $>$.

Hume, H.H. 1957. Citrus fruits. The MacMillan Company, New York, NY.

Law, J.M., M.J. Ottenhouse, and L. Provenzano. 1975. Louisiana satsuma oranges (consumer attitudes and preferences). Louisiana Rural Economist. 37:2-4.

Louisville and Nashville Railroad. (n.d). Satsuma oranges, L\&N Farmer's Handbook no. 9. $<$ http://ufdc.ufl.edu/UF00014556/00001>.

Marcus, K.A. and H.J. Amling. 1976. Alabama, p. 1-2. In: D.V. Fisher and W.H. Upshall (eds.). History of fruit growing and handling in United States of America and Canada, 1860 - 1972. American Pomological Society, Regatta City Press, Kelowna, BC, Canada.

Nesbitt, M.L., R.C. Ebel, and W.A. Dozier. 2008 Production practices for satsuma mandarins in the southeastern United States. HortScience 43:290-292.

Nesbitt, M.L., N.R. McDaniel, R.C. Ebel, W.A. Dozier, and D.G. Himelrick. 2000. Performance of satsuma mandarin protected from freezing temperatures by microsprinkler irrigation. HortScience 35:856-859.

New York Times. 1915. Turn from cotton to orange growing: Alabama planters find fruit from Japan thrives on old forest tract. 64:18. 
Overcash, J.P. 1976. Mississippi, p. 85-86. In: D.V. Fisher and W.H. Upshall (eds.). History of fruit growing and handling in United States of America and Canada, 1860 - 1972. American Pomological Society, Regatta City Press, Kelowna, BC, Canada.

Owen, T.M. 1921. Citrus fruits, p. 636-637. In: History of Alabama and dictionary of Alabama biography, vol. 1. S.J. Clarke Publishing Co., Chicago.

Reuther, W. 1973. Climate and citrus behavior, p. 280-337. In: W. Reuther (ed.). The citrus industry. 2nd ed., vol. 3. Univ. Calif. Press, Berkeley.

Rucker, B.R. 1996. Satsumaland! A history of citrus culture in west Florida. Gulf Coast Hist. Rev. 12(Fall):60-75.

Shamel, A.D. 1921. The satsuma orange in southern Alabama. Calif. Citrogr., 6, No. 9, p. 308, 328-331, figs. 6.

Swingle, W.T. 1909. The limitation of the Satsuma orange to trifoliate orange stock. Circular of the Bureau of Plant Industry 46:1-10.

Swingle, W.T. and T.R. Robinson. 1931. The Silverhill: A promising and apparently hardy strain of satsuma orange. Fla. St. Hort. Soc. 44:201-202.

Tanaka, T. 1932. A monograph of the Satsuma orange: With special reference to the occurrence of new varieties through bud variation. Taihoku Imperial Univ. Formosa (now Taiwan), Japan. University of Florida. 1934. The mandarin orange in Florida: With special reference to Satsuma. Depart. of Agriculture, Tallahassee, FL. New Series. No. 69.

U.S. Bureau of Labor Statistics. 2016. CPI inflation calculator. Washington, D.C. 10 Aug. 2016. $<$ http://www.bls.gov/data/inflation_calculator. htm $>$.

U.S. Department of Agriculture. 1945. Citrus fruits, production, farm disposition, value, and utilization of sales, crop seasons 1909-10 1943-44. U.S. Dept. Agr., Washington, D.C.

U.S. Department of Agriculture. 1952. Citrus fruits, production, farm disposition, value and utilization of sales, crop seasons 1944-45 1949-1950. U.S. Dept. Agr., Washington, D.C.

U.S. Department of Agriculture. 1967. Citrus fruits by states, 1909-10 - 1964-65, production, use, value, statistical bulletin no. 380. U.S. Dept. Agri., Washington, D.C.

U.S. Department of Agriculture. 2014. 2012 census of agriculture. U.S. Dept. Agri., Washington, D.C.

Vosbury, E.D. 1920. Citrus-fruit growing in the Gulf States. USDA Farmers' Bul. 1122.
Vosbury, E.D. and T.R. Robinson. 1929. Culture of citrus fruits in the Gulf States. USDA Farmers' Bul. 1343.

Williams, P.F. 1911. The satsuma orange. Alabama Agr. Expt. Sta. Bul. No. 157.

Winberg, O.F.E. 1928. Scandinavians at Silverhill. In: A brief history of Baldwin County. p. 7581.

Winberg, O.F.E. 1948. The satsuma. Articles from The Fairhope Courier, Fairhope, AL.

Winberg, O.F.E and G.C. Starcher. 1918. Report on freeze injury to citrus trees for 1916 and 1917, with notes on orange culture in south Alabama. Alabama Agr. Expt. Sta. Bul. No. 199.

Wolf, F.A. 1912. A field method for distinguishing certain orange stock. Alabama Agr. Expt. Sta. Circular No. 17.

Wolf, F.A. 1916. Citrus canker. Alabama Expt. Sta. Bul. No. 190 .

Wright, R.C. 1923. Coloring satsuma oranges in Alabama. USDA Dept. Bul. No. 1159.

Yelenosky, G. 1985. Cold hardiness in citrus. Hort. Rev. 7:201-238.

Yelenosky, G., R.T. Brown, and C.J. Hearn. 1973. Tolerance of trifoliate orange selections and hybrids to freezes and flooding. Proc. Annu. Meet. Fla. State Hort. Soc. 86:99-104. 